\title{
INVESTIGACIONES
}

de HISTORIA ECONÓMICA

2008, invierno, número 10. Pp. 9 a 34

\section{Asociacionismo, gremios y restricciones corporativas en la España medieval (siglos XIII-XV)}

\section{Associationism, guilds and corporate restrictions in medieval Spain $\left(13^{\text {th }}-15^{\text {th }}\right.$ centuries $)$}

\author{
JOSÉ DAMIÁN GONZÁLEZ ARCE \\ Universidad de Murcia
}

\begin{abstract}
RESUMEN
Este trabajo muestra que las asociaciones españolas prohibidas en la Baja Edad Media no pueden ser identificadas totalmente con corporaciones de oficio, sino que serían la expresión de un fenómeno más general, mediante el cual diversos grupos, especialmente la nobleza y las oligarquías urbanas, intentaron alcanzar diferentes objetivos, sobre todo políticos. Por ello, los monarcas españoles, como los europeos, emitieron restricciones que afectaron indirectamente a los gremios cuando formaron parte de esas ligas políticas o cuando los artesanos se confabularon con fines económicos para controlar el mercado. Pero ello no significó una prohibición general de las corporaciones, sino su limitación o proscripción puntual o temporal. Para demostrar esta teoría, se examina la abundante legislación anticorporativa aparecida en la España medieval y se contrasta con las conclusiones a las que diferentes especialistas han llegado en las últimas décadas. El trabajo aporta una nueva explicación para esta proliferación legislativa: la influencia que supuso la recepción del derecho romano a partir del siglo XII.
\end{abstract}

PALABRAS CLAVE: Gremios medievales, Banderías políticas, Proscripción anticorporativa, Derecho romano, España

\section{ABSTRACT}

This article asserts that the Spanish associations banned in the Low Middle Ages were not trade corporations and that those restrictions were both Spanish and European monarchs response to nobility and urban oligarchy's attempts to gain power, above all in politics, through different organizations. Guilds were indeed affected only when they took part of those political leagues or when craftsmen tried to control the market in their own benefit. And even in thoses cases the restrictions entailed just specific or temporal limitations. This assessment is based on a comprenhensive author's review of the extensive non-corporate laws developed in medieval Spain and of the explanations provided by literature in the last decades. A new possible explanation is proposed: the impact of the Roman law from the $12^{\text {th }}$ century onwards.

KEY WORDS: Medieval guilds, Political factions, Non-corporate proscriptions, Roman law, Spain

JEL Codes: N33, N43, N63, N83 


\section{Introducción ${ }^{1}$}

U Tn importante fenómeno se registró en Europa desde el Mundo Antiguo hasta la Edad Contemporánea: la aparición de instituciones y asociaciones con objetivos variopintos, algunos plenamente legales, otros no tanto. Entre éstas hubo corporaciones y gremios que incurrieron en ocasiones en abusos laborales, económicos e incluso políticos perseguidos por los reyes españoles. Ello no llevó, empero, a una prohibición genérica de los mismos, como lo prueba la proliferación de corporaciones fundadas y privilegiadas por esos mismos reyes. Otros grupos sociales diferentes de los artesanos también formaron cofradías y asociaciones con aspiraciones políticas. Sus fines espurios no fueron tolerados desde el poder, dirigiéndose contra ellas la mayor parte de las proscripciones.

Este hecho es objeto de debate desde hace más de quince años, cuando se cuestionó la tradicional interpretación que lo reducía de forma simplista a una mera animadversión antigremial de la monarquía hispana, en general, y de la castellana en particular ${ }^{2}$. Ya nadie sostiene esta teoría, sino que se enmarca el fenómeno de la limitación gremial, que no prohibición, dentro de otro más amplio contra todo tipo de asociaciones con fines diversos ${ }^{3}$. Sin embargo, queda por aclarar quiénes eran sus integrantes y qué fines perseguían, así como qué actividades desarrollaron y la relación de éstas con las prohibiciones o limitaciones a que dieron lugar, tanto a nivel de cada reino como entre los diferentes reinos españoles. Todo ello contrastando el caso español en el ámbito europeo y en el largo plazo.

Con este trabajo pretendo seguir esta línea de investigación, deslindando las limitaciones relativas al mundo laboral de las prohibiciones contra movimientos políticos contrarios a los intereses del poder establecido. Para ello parto de la hipó-

[Fecha de recepción del original, diciembre de 2006. Versión definitiva, abril de 2007]

1 Una primera versión de este trabajo fue presentada en el X Simposio de Historia Económica (Universidad Autónoma de Barcelona, 2005). Agradezco las observaciones allí recibidas y, en especial, las de los tres informantes anónimos de Investigaciones de Historia Económica que han evaluado este texto.

2 Para el marqués de Lozoya (Contreras, 1921, p. 8) los poderes públicos prohibieron los gremios infinidad de veces por causas de orden público, así como por cerrazón y exclusivismo. En modo parecido se expresan Rumeu (1944, p. 56; 1945, p. 190), García de Valdeavellano (1998, p. 287) y Carlé (1954, pp. 191-192), que se apoyan en Las Partidas y otras prohibiciones de cofradías. Más repercusión tuvo la postura de Vicens (Vicens y Nadal, 1971, p. 239), quien negó el gremialismo castellano dada la oposición monárquica. Esta afirmación sustentó un posicionamiento casi unánime de los historiadores posteriores, como Sobrequés (1977, p. 264), Martín (1983, p. 75), Gautier-Dalché (1979, p. 440), Bonachía (1983, pp. 274-277) y Estepa (1982). Otros (Uña, 1900, p. 124; López Ferreiro, 1895, p. 123) vieron en las asociaciones prohibidas agrupaciones subversivas con fines políticos, no gremios, en las que ocasionalmente participarían artesanos, como en Sahagún contra el abad y señor de la villa (siglo XII). Uña (1900), pp. 108-109, y Muñoz (2000 [1847]), p. 302.

3 González Arce (1991a). 
tesis de que solamente ciertas restricciones legislativas fueron expresamente dirigidas contra los productores agrupados en gremios y cofradías, para limitar sus excesivas atribuciones económicas más que sus objetivos políticos, mientras que el grueso de la legislación se destinó a prohibir asociaciones, formadas por miembros de la clase dirigente, que perseguían fines políticos. Para argumentar este planteamiento se han analizado las diferentes proscripciones emitidas por las cancillerías reales entre los siglos XII y XV.

\section{La Castilla de las primeras proscripciones corporativas ambiguas}

En 1611, Fernando II actuaba contra las hermandades y cofradías fraudulentas, contrarias a la iglesia y vecinos de Lugo. El Fuero de Madrid, o Fuero Viejo (1202), disponía "...que ningunos ommes nin mugeres no ssean osados de fazer cofradías nin cabildos nin ordenamientos ssin los oficiales de cada lugar que ssean a dapno del pueblo"4; en 1218, Alfonso IX "...defendo quod in Salamanca nulla sit confraria"5; y el Fuero de Ledesma "qvien confrarja fizier a danno de Ledesma, e la uilla boluir o buelta fizier enlla ujlla o enel termino, onde alcalldes sobieren uerdade, prendanlos..."6. Salvo en Salamanca, nada indica que no se pudiesen hacer cofradías debidamente autorizadas sin fines dolosos.

Sin embargo, no está claro qué se entendía por "cofradía" en estas disposiciones legales, ni si sería lo mismo que en el caso de las cofradías prohibidas en las cartas redactadas por Fernando III (1250-1251) para ser enviadas a varias ciudades castellanas $^{7}$. Estas últimas son prácticamente idénticas independientemente de la

$4 \quad$ Capella (1962), p. 9.

5 Carta confirmada por Fernando III (1231). González González (1944), doc. 367; y (1983), II, doc. 308.

6 Castro y Onís (1916), p. 281. En el de Uclés, los infractores parecen los oficiales del concejo (Fita, 1889, pp. 320344). Similares son los de Usagre y Cáceres (Ureña y Bonilla, 1907, rúbrica 126; y Lumbreras, 1974, rúb. 124), en los que se ha visto una prohibición de los gremios (Clemente, 1990, p. 35) cuando simplemente se impide la fijación de precios u otros acuerdos. La cofradía general de clérigos de Toledo se insubordinó a finales del siglo XII mediante confabulaciones y conventículos. El Papa ordenó destruir sus sellos y documentos constitucionales, aunque permitió subsistir su vertiente religioso-asistencial. Rivera (1976), II, pp. 133-145.

7 Monsalvo (1996b), pp. 110-111; y (2002), p. 151. En estos términos: “...entre uos que se fazen unas coffradrias e unos ayuntamientos malos a mengua de mio poder e de mio sennorio e a danno del conçejo e del pueblo o se fazen muchas malas encubiertas e malos paramientos, e mando so pena de los cuerpos e de quanto hauedes que estas coffradrias que las desfagades e que daqui adelante non fagades otras fuera en tal manera pora soterrar muertos e pora luminarias e pora dar a pobres e pora conffuerços, mas non pongades alcaldes entre uos nin coto malo, e pues que os yo do carrera por o fagades bien e almosna e merçed con derecho...". Carta de Alcaraz en Pretel (1974), pp. 136139, y (1986), pp. 264-265; Romero (1995), p. 136, y Pérez Marcos (1995), pp. 167-168. Para Uceda, Cuenca, Guadalajara y Calatañazor, González González (1983), pp. 387-389, 398-400, 412-415; y para Segovia, Colmenares (1969), pp. 380-382, y Contreras (1921), p. 18. 
localidad de destino y de la realidad económica de la misma, hecho que nos lleva a concluir que eran una mera reproducción diplomática y que las cofradías proscritas no serían gremios, pues en estas fechas no podían poner en peligro la autoridad real en lugares con tan poco desarrollo artesanal como Alcaraz o Calatañazor, poco más que pueblos y para los que hemos localizado, entre otros, dicha documentación. Se podría esgrimir entonces que estaríamos ante una reproducción jurídica a imitación de las prohibiciones realizadas para Segovia o Cuenca, donde los artesanos sí habrían alcanzado peligrosas cotas de poder político. Ésta era al menos la interpretación tradicional. Sin embargo, la única relación que se puede establecer entre cofradías y artesanos es que en las cartas se dispone, en el párrafo anterior a su proscripción, que éstos no podían ejercer de jueces ni entrar a formar parte de los concejos ${ }^{8}$. Pero son dos disposiciones sin relación necesaria; por tanto, ¿quiénes fueron entonces los que integraron las mencionadas formaciones? Probablemente, los miembros del concejo, por lo que estaríamos ante una bandería urbana con finalidad política9 ${ }^{9}$. En todo caso, no quedaron prohibidas las cofradías, sino solamente aquéllas con fines ilícitos.

Alfonso X prosiguió la labor de su padre. Si bien continuó haciendo uso de ordenamientos locales similares a las cartas de su progenitor ${ }^{10}$, prefirió el más universal marco de las Cortes para ello ${ }^{11}$.

8 Lo que explicaría su debilidad política en Castilla. Monsalvo (2001), pp. 309-310.

9 González Arce (1991a), p. 318, y Fuentes (2003), p. 165. En Alcaraz, Alfonso VIII fundó dos cofradías nobiliarias, objeto de la carta de disolución de Fernando III, quien consintió una similar de caballeros que cooperaron en la toma de Sevilla. En ésta, Alfonso X fundó (1276) una hermandad de cristianos viejos. Pretel (1974), p. 43; Romero (1995), pp. 136-137, y López Martínez (1948), pp. 218-219.

10 Caso de Compostela (1253), Cuenca, Segovia y Burgos (1256). López Ferreiro (1895), p. 226; Ureña (1935), pp. 859-860; Chacón (1998), doc. 12; Represa (1949), p. 293; Martínez (1985), p. 124; Romero (1995), p. 137, y García Rámila (1945), pp. 232-233. En Segovia “...se fazian unas cofradias e ayuntamientos malos a mingua de mio poder e de mio sennorio e a danno de su concejo e del pueblo, o se fazian muchas malas encubiertas e muchos malos paramientos...". En Sahagún, se prohibió (1255) que se hiciesen cofradías y se mandó deshacer las existentes (Muñoz, 2000 [1847], p. 317; y Meñaca, 1982, p. 204). Años antes los zapateros de Santiago pretendieron construir una sede gremial con el pretexto de alberguería para pobres, a lo que se opuso el arzobispo. Fernando III ordenó (1250) su derribo, prohibiendo las cofradías "ca estos aiuntamientos nunca se leuantan fuera para mal", prohibición que repitió su hijo en 1253 (López Ferreiro, 1895, pp. 226-228). Algunos sínodos refrendaron las prohibiciones (Sánchez, 1975, y 1978, p. 396), que no siempre fueron respetadas por los concejos, como muestra el caso de Baeza (1329), que consintió hacer cofradías para librar pleitos por sus propios alcaldes (Rodríguez, 1983, II, doc. 29).

11 Valladolid (1258) y Jerez (1268), en Cortes (1866), I, pp. 61-62 y 79-80. Sevilla (1252): “...mando que non fagan cofradias nin yuntas malas nin nengunos malos ayuntamientos [...] Et que non aya hy ortos alcaldes nengunos para iuzgar en las cofradias si non los que fueren puestos por mi en las uillass o por el fuero...", García Rámila (1945), p. 210. 


\section{Las Partidas y las limitaciones gremiales}

La más conocida restricción corporativa de Castilla es la Ley II ("De los cotos e las posturas, que ponen los mercadores ente si, faziendo juras e cofradias"), del Título VII de la Quinta Partida ${ }^{12}$. La primera información que aporta es que existían gremios, al menos de hecho, con un grado de cerrazón y exclusivismo que solamente alcanzaron otros europeos en fechas muy posteriores ${ }^{13}$. La segunda, que por ese motivo el rey intervino para limitar los excesos. Pero, ¿lo hizo prohibiendo los gremios como tradicionalmente se pensó? Se ha adelantado que la respuesta ha de ser negativa.

Esta ley, Las Partidas, simplemente restringió los aspectos más amenazantes del corporativismo. Vedaba las cofradías, posturas (precio o pacto) y cotos (postura o tasa) sin aprobación real. Prohibía, asimismo, las cofradías o juras para fijar precios (oligopolios colusivos) y la existencia de gremios cerrados que impidiesen la incorporación de nuevos miembros, la terminación de una obra por otro artesano o la enseñanza del oficio a aprendices no emparentados con los agremiados; es decir, el llamado gremialismo integral ${ }^{14}$.

Con esta obra, Alfonso X reintrodujo el derecho romano mediante la recepción de aspectos del derecho tradicional (Digesto) y del último derecho tardorromano y bizantino (Código y Novellae de Justiniano). La similitud del Código y Las Partidas es manifiesta:

12 "Cotos e posturas, ponen los mercadores entre si, faziendo juras e cofradias, que se ayuden vnos con otros, poniendo precio entre si por quanto den la vara de cada paño, e por quanto den otrosi el peso e la medida de cada vna de las otras cosas, e non menos. Otrosi los menestrales ponen coto entre si por quanto precio den cada vna de las cosas que fazen de sus menesteres. Otrosi fazen posturas que otro ninguno non labre de sus menesteres, sino aquellos que ellos reciben en sus conpañias. E aun que aquellos que asi fueren recebidos que non acaben el vno lo que el otro ouiere començado. E aun ponen coto en otra manera, que non muestren sus menesteres a otros sino aquellos que descendieren de sus linajes dellos mismos...", Alfonso X (1985 [1555]), III, p. 36v.

13 González Arce (1991a), p. 321. Sin que los gremios hubiesen alcanzado un reconocimiento de derecho ni se hubiesen consolidado, como parece interpretar Gautier-Dalché (1993, p. 17). Poca actitud antigremial se puede atribuir a un texto que en otro apartado establece que “...tenemos por derecho que los maestros e los escolares puedan esto fazer en estudio general [...] conuiene que se ayunten todos a derecho quando les fuere menester en las cosas que fueren a pro de sus estudios e amparança de si mismos e de lo suyo. Otrosi pueden establecer de si mismos on mayoral sobre todos que llaman en latin rector del estudio al qual obedezcan en las cosas conuenibles e guisadas e derechas. E el rector deue castigar e premiar a los escolares que non leuanten vandos nin peleas con los omes de los logares do fueren los escolares ni entre si mismos", Alfonso X (1985 [1555]), Partida II, Título XXXI, Ley VI, vol. I, p. 115r.

14 Monsalvo (2001), p. 310. Esta ley fue aplicada en Cuenca (1468), ciudad con gremios desarrollados, por orden de Enrique IV para que no consolidasen prácticas monopolísticas propias de un corporativismo cerrado y excluyente. Iradiel (1974), p. 85. 
“...nadie se atreva a ejercer el monopolio de cualquier vestido, o del pescado [...], y que nadie se conjure o pacte, habiendo celebrado reuniones ilícitas, para que las especies de los diversos objetos de negociación no se vendan por menos de lo que entre sí hubiesen establecido [...] tengan en absoluto prohibición para concertar pactos entre sí, a fin de que ninguno acabe la obra que a otro se haya encomendado, o de que otro coja el encargo que a otro se le había hecho [...] Más si alguien se hubiere atrevido a ejercer un monopolio, sea condenado [...] Mandamos, además, que si los principales de las demás profesiones se hubieren atrevido, congregándose de este modo, a obligarse con pactos en lo sucesivo, o para tasar los precios de las cosas, o sobre cualesquiera convenciones ilícitas, sean castigados" 15 .

Poco carácter antigremial cabe atribuir, pues, a Las Partidas, que más que reprimir una situación real parecen atender a una imitación legislativa de lo contenido en el Código, al que copian casi de forma literal, hasta el extremo de que la pena prevista en la obra alfonsí es exactamente igual a la fijada en su día por Zenón: "cincuenta libras de oro".

En 1351, las Cortes de Valladolid refirieron a Pedro I su preocupación por las atribuciones alcanzadas por las corporaciones artesanales ${ }^{16}$. El acuerdo alcanzado es un texto muy semejante a Las Partidas, de lo que cabe inferir que estas últimas tuvieron una repercusión nula, pues un siglo después el exclusivismo, la cerrazón y los oligopolios colusivos estaban aún más extendidos. Ambas disposiciones, además, aparecieron en plena crisis inflacionista, que se quiso atajar promoviendo la oferta. De ahí que fueran proscritas ciertas prácticas gremiales, pero no los gremios, porque implícitamente se entiende que las corporaciones que no realizasen estas colusiones no se verían afectadas ${ }^{17}$.

15 Lib. IV, Tít. LIX (“De los monopolios y de las reuniones ilícitas de los negociantes, o de las convenciones prohibidas e ilícitas de los artífices, de los empresarios de obras y de los bañeros”), Leyes 1 y 2. García del Corral (1998), IV, pp. 530-531.

16 "...fazen cofradias apartadas e posturas sobre sus ofiçios e menesteres, que non labren de noche nin cojan omes en los of fiçios e menesteres, sinon si ffueren de sus linages o moços pequennos quelos siruan por çiertos annos, et que non consientan labrar a otro ninguno sinon al que fuere de su cofradia, et otras muchas posturas que ffazen e guardan por ffazer poca lauor; e que por quelo uendan mas caro, que ponen coto quelo vendan a vn preçio...", Cortes (1866), II, pp. 28-29.

17 González Arce (1991a), pp. 320-322. Corrobora esta tesis que las Ordenanzas de Sevilla (Ordenanzas, 1975 [1632], fol. 85r) recojan la prohibición de 1351 a comienzos del siglo XVI, cuando casi todos los oficios contaban con estructura gremial; ahora bien, no les serían consentidas las prácticas monopolísticas. Alfonso XI dispuso que si los menestrales de Sevilla hiciesen ordenamientos propios o posturas debían "ser muertos" por ello, siempre que falseasen los pesos y medidas o defraudasen los oficios (González Arce, 1991b, p. 171); disposición por otro lado también incorporada a las Ordenanzas (1975 [1632], fol. 84v). Un ejemplo lo tenemos en los trompeteros, que "...fazen liga entre sí que non vayan a las dichas onrras saluo por grandes quantías de mrs.". Dicho rey dispuso (1327) que los jurados de cada collación conociesen los ayuntamientos de gentes (González Arce, 2003, pp. 251 y 382). En las Cortes de 1371 se informó que los pescadores cántabros y vascos compraban en Galicia y Asturias pescado fresco y ballenas, para salarlos y revenderlos, pero los gallegos y asturianos habían realizado "posturas e cofradias e que gelo non querian consentir", que Enrique II no prohibió, sino ordenó proceder como en tiempos de su padre (Cortes, 1866, II, pp. 214-215). 


\section{La Corona de Aragón: prohibiciones ambiguas y limitaciones gre- miales}

Las restricciones gremiales se extendieron también por la Corona de Aragón, pero con menor repercusión. Se trata de una coincidencia temporal que requiere ser analizada antes de proseguir con el caso castellano.

Las Partidas y las Cortes de 1351 tienen, en materia anticorporativa, su alter ego en los Furs de Valencia. En el Llibre II, rúbrica III, se habla "De convinençes e de conspirations, ço és de mals enprenimens ${ }^{18 "}$; en el Fur III, dado por Jaime I, puede leerse: "Mercaderes no sien osats fer alcunes convinençes entre ells, que coses o mercaderies compren o venen a cert preu; e si ó faran, sien condempnats pecunialment, ço és en aver". De nuevo lo dispuesto en el Código. No cabe mayor similitud entre disposiciones restrictivas pertenecientes a reinos diferentes. Igualmente hay paralelismo en el tiempo: los reinados de Jaime y Alfonso son contemporáneos, como los de los dos Pedros. Sin embargo, en los Furs, al contrario que en Las Partidas y en las Cortes, no se ha visto una prohibición en toda regla de los gremios, algo no sorprendente dada la aquilatada tradición de Jaime I y Pedro IV como fundadores, protectores y confirmadores de gremios y cofradías, como también lo fueron, por su parte, los reyes castellanos.

¿Cómo explicar entonces las proscripciones de las corporaciones valencianas cuando Jaime I les asignó puestos de relevancia en el gobierno municipal de la capital? Cabe considerarlas como relativas a cofradías no gremiales, de carácter político o subversivo, como en Castilla, o bien como el vedamiento de ciertos abusos realizados por los gremios. Para Iradiel ${ }^{19}$, dicha prohibición atendería a motivos contingentes y concretos, que tradicionalmente han sido interpretados como abusos, ligas y monopolios. Sin embargo, una eventual intervención económica monopolista no habría llevado a una postura tan drástica. Ésta se entendería mejor si hubiesen concurrido, además, una alianza entre el poder señorial y monárquico y una solicitud de ciertos oficios privilegiados en defensa de sus intereses: los señores querrían evitar que los artesanos siguiesen ganando poder político en el gobierno municipal, mientras que los oficios privilegiados no querrían compartir su poder con otros nuevos.

18 Colón y García (1978), II, pp. 135-145. En el Fur VI, de Pedro IV: “...los calafats hajen feta ordinació entre si que nungun d'ells no prengua sinó hun dexeble o aprendiz per aprende lo dit ofici, per ço que sien pochs en nombre e hajen més que obrar e major loguer...". Y en el Fur XXIII, de Jaime I: "Vedam sots pena del cors que no sien feites confradries, sagramentals ne conspirations, ço és mals enpreniments entre alcuns pobladores o habitadors del regne de València e de la ciutat, o entre alcuns offcials". ¿Se refiere a simples menestrales o a los oficiales del poder político?

19 Iradiel (1993), pp. 266-267. 
Para entender las intenciones de Jaime I podemos recurrir a sus sucesores, que autorizaron la constitución de nuevos gremios o cofradías. Alfonso IV, en los estatutos concedidos a varias cofradías (1329), informa de anteriores abusos, probables causas de las prohibiciones, consistentes en ayuntamientos, actos ilícitos y monopolios. Por ello su padre, Jaime II, las proscribió igualmente ${ }^{20}$.

Respecto a Aragón, la prohibición de Jaime II fue repetida en las Cortes de Daroca (1311). Allí fueron vedados los monopolios y cofradías por ser nocivos a la "causa común" y contrarios a la jurisdicción real, como el caso del fuero "ut monopolia"21, recogido entre los del reino de Aragón. Sin embargo, las excepciones fueron muy numerosas.

Sin abandonar Aragón, en Jaca ${ }^{22}$ (1238) el concejo prohibió los cotos y juras de los oficios artesanales, por participar en banderías urbanas. Sin embargo, no lo hizo con las ordenanzas (cotos) de oficio con consentimiento de los jurados locales. Un siglo más tarde (1338), Pedro IV confirmaba unos estatutos redactados por los jurados de la ciudad que prohibían los colegios y otras asociaciones o cofradías ${ }^{23}$.

En 1522, varias ciudades se dirigieron a Carlos I para solicitarle que suprimiese las cofradías de oficio, argumentando Zaragoza que "los confrades se ajuntan fazen sus ordinaciones y monipodios en que encareçen todas las cosas de sus officios (...) en bollicios y con mano armada se levantan a veces unos contra otros y a veces contra los que tienen el regimiento desta ciudat". Como respuesta, el rey abolió en las Cortes de Monzón (1528)

20 Los abusos fueron "Verumtamen quia ex congregationibus et conventiculis hominum non nunquam monapolia et illicita emergunt consilia que illicitis actibus ausun prebunt serenissimus dominus Jacobus recolende memorie rex Aragonum genitor noster confratrias omnes civitatis et regni Valencie excepta confratria que dictur sancti Jacobi reprobavit easque cassavit et irritavit ac perpetua sustulit sanccione inter quas confratriam olim pro pylerios dicte civitatis editam el multo tempore observatam noscitur sustulisse", Bofarul (1876), pp. 71 y 65-66; Rumeu (1944), pp. 56-58; y Tramoyeres (1979 [1889]), pp. 42 y 49. No obstante, este rey aprobó nuevas cofradías, como las de calafates (1306); marineros (1306), hasta ahora desconocida y que no podía hacer coaliciones, juras ni ordenanzas sin autorización real; y pescadores del mar (1308), con las mismas limitaciones (Bofarull y de Sartorio, 1876, pp. 35-37). Previamente (1303) otorgó privilegios al colegio de pescadores de La Albufera (González Arce, 2006 y 2007).

21 "Quia propter monopolia, conventicula, emprendimenta, congregationes, convenientias atque pacta quae facicunt in suis confrariis et congregationibus, cerdones, pelliparii, sartores [...] et alii aliorum quorumque ministeriorum, operariorum et officiorum: multa damna perveniunt cunctis gentibus nostri regni, et cedunt in diminutionem iurisdictionis nostrae [...] cassamus et in perpetuum anullamus omnes confratrias, emprendimenta, monopolia, conventicula, convenientias atque pacta inia inter praedictos ministrales...", Colmeiro (1863), p. 306; y Falcón (1997), p. 43, (1991), p. 201; y (2001), p. 13.

22 "...desfagan totas las unitazs e las enpresions qu'eran entre menestrals ni en totz los mestiers de Iacca, assi che d'aqu'enant los uns als altres no sian tiengats per cot ni per iura ni per omenage..." "Demas debedaren, che nungun uezin de Iacca ni habitador sia tan ardit de far aplega ni menestrals ni altres omnes ensemble aplegar, ni amniar per iura, ni per omenage, per razon de bando ni per baralla [...] empero si por abentura en nungun mestier era ops enpresion ni cot, che sia feit con uolontat e con atorgament dels Iuratz", Oliver (1908), p. 351; y Ubieto (1975), p.135. 
todo tipo de cofradías y hermandades de artesanos, así como sus privilegios y ordenanzas $^{24}$. Lo que no obstó para que confirmase diversas ordenanzas de oficio. De nuevo en el siglo XVII se aprobaron diversas restricciones gremiales ${ }^{25}$.

Para acabar con la Corona de Aragón, haré una breve referencia a Cataluña, donde las prohibiciones tuvieron muy escasa repercusión. En 1293 Jaime II ordenó a Lleida deshacer confederaciones o congregaciones ilegales de menestrales, carentes de autorización real. Pero dos años más tarde dio un privilegio anulando la prohibición y facultando a los menestrales para elegir mayorales que convocasen a los del oficio anualmente, con el cometido de tratar y organizar las obras pías ${ }^{26}$.

\section{Navarra y las disposiciones anticorporativas}

Navarra también registró disposiciones restrictivas. En Estella (1246) fueron disueltas todas las cofradías, medida que podría apuntar a conflictos mercantiles más que políticos. La misma fue recurrida ante Teobaldo II, quien la ratificó hasta que no se pronunciasen los jueces superiores. Poco después, el rey autorizó los estatutos de una nueva cofradía recién constituida, revalidó aquéllas prohibidas y autorizó la fusión de otras. Más adelante, Carlos el Calvo (1323) prohibió dos por la violencia que habían protagonizado en forma de auténticos bandos de finalidad política ${ }^{27}$.

En ningún momento se identifica a alguna de estas cofradías como laborales, aunque en los fueros de Tudela, dados por Alfonso I y rectificados en 1330, sí encontramos una restricción gremial ${ }^{28}$. Ésta ha de inscribirse en la proliferación corporativa del siglo XIV, dónde se mantuvo estable el número de cofradías devocionales,

24 "Han sido perpetuamente cessados, revocados y anullados todos e qualesquiere collegios, ajuntamientos, congregaciones, hermandades, confrarias y qualesquiera statutos, pactos, prometimientos y asignaciones y todos qualesquiere privilegios, facultades, poderes y permisos [...] dados, concedidos y en qualesquiere manera otorgados a todos e qualesquiere officiales, artesanos, obreros, menestrales, artistas y colegios para fazer las susodichas congregaciones, ajuntamientos, confradias, colegios y herrmandades", Falcón (1991), p. 202.

25 Falcón (1994), p. 67; y Sancho (1925), pp. 36-38.

26 Pérez Pérez (1973), p. 247. Tortosa redactó un Código de Costumbres (1279) que contenía la prohibición de cofradías y confabulaciones entre menestrales o corredores. Martín Granizo (1950), II, p. 42.

27 Carrasco (1993), pp. 233 y ss.

28 Uña (1990), p. 142; y Meñaca, (1982), p. 204. En los siguientes términos: “...los paramientos de las cofrarias de los menesteres de toda manera de gent que son a deservicio del señor rey, é á dinio grant de pueblo, que sea la mercé del sennor rey que sean desfechas [...]; en razon de las cofrarias, que son fechas por los menestrales, cada uno de su mester, es ordednado, por razon que muitos males se end siguen al pueblo, que sean desfeitas [...]; si algunos estatutos, ó paramientos, se hobiesen á facer por guardar lures menesteres de enganno á proveito del pueblo, que los dichos paramientos é ordenanzas sean fechas de voluntat é espreso consentimiento del alcalde, del justicia, é de los jurados...", Muñoz (2000 [1847]), pp. 424-425. 
pero creció el de oficios. En Estella, pese a las prohibiciones, las corporaciones siguieron desarrollando sus actividades sin licencia del rey, redactando ordenanzas, formando uniones, juras, ligas y banderías de unos vecinos contra otros. Por ello fueron nuevamente suspendidas (1346) y se compiló información precisa sobre sus estatutos, cuentas y gastos. Luego fueron colocados en ellas oidores y veedores de sus reglas. En el caso de las cofradías de menestrales se pretendió que no perjudicasen a los peregrinos cuando comprasen mercancías. Tras varios años de prohibiciones teóricas, la monarquía reconoció que existían fraternidades secretas y escondidas, sin permiso ni licencia real. Por su parte, Carlos III prohibió (1411-1412) todas las cofradías de menestrales, especialmente algunas de Pamplona ${ }^{29}$.

Un ejemplo de la ineficacia de este programa proscriptor son las conclusiones del Consejo de Navarra, al que el de Castilla encargó en 1770 un informe sobre los gremios y cofradías existentes por entonces. Con relación a los navarros, aquél reconoció que estaban prohibidos desde las Cortes de Sangüesa (1561), pero que eran tolerados por la costumbre y realizaban sus actividades a la luz pública con el consentimiento tácito de las autoridades ${ }^{30}$.

\section{La Castilla de las ligas nobiliarias y las banderías urbanas}

En Castilla siguieron proliferando las prohibiciones, en una nueva retahíla legislativa de Juan I a Enrique IV, ahora menos ambigua, permitiendo una identificación más fácil de sus protagonistas, pero igualmente retórica. Si las "ligas, monipodios, ayuntamientos, pleytos omenajes, juramentos, contratos y firmezas que han hecho hasta aqui", realizados por "infantes, duques, condes, maestres, priores, marqueses, ricos hombres, caualleros y escuderos" y prohibidos por Juan I en las Cortes de de Guadalajara (1390) y por Enrique III en las de Madrid (1393), son similares a las ambiguas cofradías proscritas en reinados anteriores, no se precisan más evidencias del carácter político y no gremial de las mismas ${ }^{31}$.

29 Carrasco (1993), pp. 238-240.

$30 \quad$ Arias y López (1998), p. 689.

31 González Arce (1991a), p. 323; Cortes (1866), II, pp.425-427 y 529-530; y Romero (1995), p. 138. Esta legislación pervivió hasta el siglo XIX al incluirse en la Nueva Recopilación (1982 [1640], II, VI, VIII, XIV, fols. 333r335r). Fueron asociaciones muy atractivas porque cohesionaban intereses comunes, como el linaje, vasallaje y clientelismo (Romero, 1995, p. 139). Álvaro de Luna (1423) recibió el apoyo de varios grandes del reino, que firmaron una carta de confederación en su favor, que, como otras juramentaciones, contó con el beneplácito del rey (Calderón, 1999, p. 53). Tales monipodios (asociaciones subversivas) no fueron sólo de poderosos, sino también de medianos que se confederaron contra éstos. En 1389 el señor de Oñate emitía un 
Con Enrique IV vuelve a aparecer entre las asociaciones proscritas el término "cofradía". En las Cortes de Toledo (1462) se informa de delitos cometidos por "algunas ligas e monepodios e confederaçiones [...] so color de cofadrias". Que el rey ordenó deshacer prohibiendo hacer otras nuevas, "saluo en las hermandades e cofadrias que se mostraran ser aprouadas por $\mathrm{mi}^{\prime \prime 32}$. Con poca repercusión, pues debió repetir la prohibición en las Cortes de Santa María de Nieva (1473), con nuevas argumentaciones ${ }^{33}$. Aunque no se especifique qué asociaciones ilícitas adoptaron ese elaborado manto de respetabilidad ni sus fines, por su complejidad e importancia, así como por la gravedad de sus acciones, debieron estar más cercanas a finalidades políticas que a objetivos de carácter laboral. Así lo demuestran las prohibiciones conocidas ${ }^{34}$.

perdón a sus vasallos que habían hecho "juramiento e monopodio e conspiraçiones a desonrra mia y de mi señorio y hordenaron entre si cofradias vedadas y avido estatutos e posturas en uno en la dicha mi tierra obligandose, so ziertas penas, los unos a los otros, de guardar e tener las hordenanças malas por ello hechas e de no se partir ni falleçer los unos a los otros, haçiendo entre si pleito menaxe y jurando ansi al cuerpo de Dios" (Zumalde, 1994, pp. 3-6). La oligarquía urbana se organizó en forma de linajes, cofradías y bajo denominaciones como gremios, cabildos y concejos. Val (1994), p. 160.

32 Cortes (1866), III, pp. 728-729. Previamente había prohibido la participación de obispos, abades y otros clérigos en bandos o ligas. Romero (1995), p. 140.

33 “...juntan cofradias, y para colocar su mal proposito toman aduocacion y apellido de algun santo o santa, y llegan asi tras muchas personas conformes a ellos en los deseos, y hazen sus ligas y juramentos para se ayudar, y algunas vezes hazen sus estatutos honestos para mostrar en publico, diziendo que para la execucion de aquellos hazen las tales cofradias, pero en sus hablas secretas y conciertos tiran a otras cosas que tienden en el mal de sus proximos y escandalos de sus pueblos, y como quier que los ayuntamientos ilicitos son reprouados y prohibidos por derecho y por leyes de nuestros reynos, pero los inuentores destas nouedades buscan tales colores y causas fingidas, juntandolas con santo apellido y con algunas ordenanças honestas que ponen en el comienço de sus estatutos por donde quieren mostrar que su dañado proposito se pueda desculpar y lleuar adelante...", Nueva Recopilación (1982 [1640]), II, Libro VIII, Título XIV, Ley III; Cortes (1866), III, p. 881; y Romero (1995), pp. 140-141.

34 En San Vicente de la Barquera (1455) la cofradía de pescadores se opuso a que sus miembros participasen en formaciones clandestinas con finalidad política y les prohibió "que no salgan armados a los tales alborotos a favor de bandos", pues de lo contrario "no le hagan nin habemos por cofrades". En 1480 los Reyes Católicos prohibieron a los pescadores y otros oficiales de Laredo, Santander, San Vicente y Castro Urdiales que se aliasen con caballeros o gentes poderosas en sus bandos y parcialidades (Archivo General de Simancas [AGS, en adelante], Registro General de Sello [RGS], 1480-5, fol. 214). En 1477 escribieron al corregidor de Toledo acerca de las ligas, confederaciones y cofradías que excedían lo tocante al servicio de Dios, algunas hechas entre "acostados" y caballeros (AGS, RGS, 1476-11, fol. 779). Al corregidor de Cuenca, le ordenaron que no consintiese las cofradías de carácter nobiliario, vedándolas como en Toledo; dado que la prohibición afectaría a las corporaciones laborales, dispusieron que se permitiese en Cuenca la elección de prebostes y veedores en las cofradías y que se respetasen los gremios (Rumeu, 1944, pp. 102-105; Sáinz, 1973, pp. 152 y 514-516; Solórzano, 1999, pp. 42-43; e Iradiel, 1974, pp. 86-87). En Chinchilla (1497) se produjeron escándalos en torno a la elección de los oficios concejiles (AGS, RGS, 1497-1, fol. 335). En Lequeitio (1488) se registraron enfrentamientos entre linajes, pese a la hermandad y comunidad para evitar luchas "bandericias" (AGS, RGS, 1488-5, fol. 205). Las ordenanzas de Azcoítia contra bandos y parcialidades de poderosos datan de 1484 (AGS, RGS, 1484-1, fol. 77); las de Portugalete, del año siguiente (AGS, RGS, 1485-7, fol. 78). En 1493, las de ¿Plentzia?, redactadas 7 ú 8 años antes, no impidieron que ciertas personas se tornasen a juntar (AGS, RGS, 1493-7, fol. 218). Finalmente, en 1494 los Reyes escribían a los concejos vizcaínos prohi- 
Algunos artesanos imitaron esas organizaciones clandestinas para sus pequeños fines económicos. En Salamanca los curtidores y zapateros formaron (1437) una cofradía para "muchas colusiones e encobiertas e monipodios e fabras", así como "yliçito ayuntamiento e colegios yliçitos" para subir los precios. Prohibidos por el concejo, no cejaron empero, pues constituyeron (1493) una falsa cofradía piadosa para exigir cuotas semanales a los obreros contratados, bajo la amenaza de despido; cohecho denunciado por un zapatero, así como la falta de cometidos píos de la cofradía, que había sido constituida contra lo dispuesto en las Cortes de $1462^{35}$. En Valladolid, los Reyes revocaron las cofradías artesanales que encarecían los precios, "en quanto toca a las cosas de mercaderias e ofiçios, saluo para las cosas espeçiales de sus enterramientos e mortuorios" ${ }^{\prime 36}$. En Segovia, los pelaires denunciaron fraudes de los fabricantes de

biendo hacer parentelas y parcialidades ("ni tengais confradias ni otros allegamientos por via de bandos ni por nonbre de los dichos linages ni alguno dellos"; Hidalgo, Largacha, Lorente y Martínez, 1986, pp.186-188). Ello no evitó que se reprodujesen, como denunció en 1499 la Cofradía de Ibarri, que por no querer entrar en bandos y parcialidades vio cómo otras se aprovechaban de sus montes, cuando no los quemaban directamente (AGS, RGS, 1499-10, fol. 358). En 1477, los Reyes enviaron una provisión a la provincia de Guipúzcoa para que no se hiciesen ligas ni monipodios por parte de algunos caballeros (Recalde y Orella, 1988, II, p. 180). En 1491, San Sebastián informó que contra las nuevas ordenanzas concejiles se habían levantado algunos poderosos en forma de ligas y monipodios (AGS, RGS, 1491-11, fol. 88). En una asamblea del clero (Sevilla, 1478), se solicitó a los Reyes que las cofradías se sometiesen a la justicia eclesiástica y dejasen de realizar actividades ilegales (Sánchez, 1991, p. 26). En Málaga, al año siguiente de formarse el concejo, “ciertos cavalleros o escuderos desta çibdad fasyan confederaçion, ligas e monipodios" (Ruiz, 1989, p. 129). En Córdoba (1498) la oligarquía también realizó bandos, por lo que Fernando el Católico promovió unas ordenanzas contra ellos (AGS, Cámara de Castilla, Diversos, Legajo 10, documento 2). A una cofradía de caballeros del lugar obligaron (1480) a dar información sobre sus cuentas (AGS, RGS, 1480-5, fol. 245). En Úbeda y Baeza había bandos y parcialidades a los que acudían los escuderos y ciudadanos, aliándose a los caballeros en sus enfrentamientos. Para evitarlos, el corregidor redactó ciertas ordenanzas (AGS, RGS, 1498-5, fol. 1). De algunas cofradías fraudulentas desconocemos su filiación, pero no fueron de menestrales, por su escaso número; como en Hontiveros (Ávila), donde algunas cofradías y devociones de santos protagonizaban escándalos poniendo oficiales que usurpaban la justicia real (AGS, RGS, 1488-3, fol. 144). Tampoco debieron de ser laborales, pues no consta su existencia, las cofradías abulenses que imponían la imposibilidad de apelar los juicios de sus mayordomos ante la justicia ordinaria, lo cual fue anulado por ir contra la jurisdicción real (AGS, RGS, 1489-1, fol. 31). En Logroño algunos vecinos defraudaron en el pago de alcabalas, y para no ser prendados hicieron una "liga e monipodio, se juntaron en la yglesia de Sant Batolome desta dicha çibdad e que alli juntos fisieron e hordenaron vna cofradia que desian de los coronados" (AGS, RGS, 1498-8, fol. 142). De la participación en parcialidades y bandos no escaparon ni las universidades. En 1462, Enrique IV prohibía a la de Salamanca que sus profesores y alumnos lo hiciesen en los locales, bajo pena de ser apartados "del gremio, y Vniversidad del Estudio" (Nueva Recopilación, 1982 [1640], I, fol. 26r, I, VII, I-II). Este término "gremio" hace referencia al cuerpo de doctores y catedráticos universitarios, y no a una asociación artesanal, pero no podemos pasar por alto que una de las primeras apariciones de este vocablo fue para amenazar con la expulsión del "gremio" a los que participasen en bandos y parcialidades. Monsalvo (1996b), p. 57, y (2001), p. 312; Vaca, Cuenca, Sánchez y Matas (1984), pp. 85-86; y López Benito (1983), pp. 180-181. Allí se vivieron además conflictos entre las cofradías devocionales, como la de San Antón y Santa Margarita, por cuenta de los banquetes. AGS, RGS, 1493-9, fol. 245.

36 AGS, RGS, 1484-3, fol. 197. Ello afectó en todo caso a su capacidad de fijar precios, pues siguieron existiendo con facultades gremiales. 
paños, que hacían ligas y monipodios para no encargarles trabajo y darlo a forasteros $^{37}$. En Ciudad Real, la liga de zapateros y borceguineros se usó para defraudar la renta de la zapatería y la alcabala ${ }^{38}$. En Murcia (1481), los tintoreros hicieron ligas y monipodios para no trabajar paños de ciertos pelaires ${ }^{39}$. En Sevilla (1476), los cordoneros realizaron avenencia para vender sólo cuerdas a determinados rederos bajo su control; deshecha por el concejo, hacia 1482 realizaron un monipodio situando alcaldes para controlar a las rederas. De nuevo prohibido, pues éstas eran fiscalizadas por los de los pescadores. En 1484 Isabel I confirmó las sentencias concejiles ${ }^{40}$. En Córdoba, los curtidores "fizieron entre sy liga e monipodio de non çurrar los cueros al preçio que fasta aqui los çurrauan"; fueron sancionados, pero los borceguineros denunciaron que no cejaban en estas prácticas oligopolísticas. Estos últimos participaron en colusiones sobre las tiendas que "non pueden haser liga ni monipodio de las non pujar onos a otros ni sobrello haser hordenança alguna". A pesar de lo cual "han fecho entre sy çiertas cofradias e que en ellas han fecho çiertas hordenanças de se guardar vnos a otros e de no se faser daño", en contra de una carta dada por los Reyes ${ }^{41}$. En Santiago de Compostela (1495), "los mas de los ofiçiales tienen cofradias, y que los dichos ofiçiales que entran en ellas no consienten a ninguno que venda por menudo ni gran cosa en la dicha çibdad, ni que ponga tienda en su ofiçio, sin que se iguale con la tal cofradia"42. En Laredo, un pescador de sardina denunció una cofradía, en forma de liga y monipodio, en la que solamente sus miembros podían pescar ${ }^{43}$. En Burgos (1505), su gremio-cofradía-universidad de mercaderes realizó una liga y monipodio, prohibido por la reina Juana, para que nadie cargase mercaderías en barcos bilbaínos, tras el enfrentamiento entre ambas ciudades derivado de la escisión de su consulado conjunto en Brujas ${ }^{44}$. En Vitoria el cabildo de sastres redactó ordenanzas que obligaban a los judíos a no trabajar fuera de la ciudad, los cuales denunciaron esta liga y monipodio ${ }^{45}$. En San Sebastián, Enrique IV se dirigió a la cofradía de pescadores (1460) sobre "ayuntamientos so color de cofradia y diciendo ser mayorales y cofrades de la cofradia de San pedro y dizen que han hecho contratos y ligas y monipodios y juramentos en que entre otras cosas dize que se contiene que no se guarden

AGS, RGS, 1495-3-1, fol. 175.

AGS, RGS, 1495-1, fol. 364.

González Arce (2000), p. 193.

Carande y de Mata Carriazo (1968), II, pp. 477-482. En la ciudad (1411) “auia casas que se llaman monesterios de malas mugeres que vsauan mal de sus cuerpos en pecado de luxuria e que tenían vna mayoral a manera de abbadesa [...] que así estauan ayuntadas por manera de colegio...", González Arce (2003), pp. 400-401.

AGS, RGS, 1487-9, fol. 180; y RGS, 1491-2, fol. 31.

García Oro (1987), pp. 69-70.

AGS, RGS, 1495-8, fol. 54.

Enríquez, Hidalgo y Martínez (2000), pp. 930-931, 1074-1076 y 1182-1122; y García Fernández (2005), p. 284.

AGS, RGS, 1488-7, fol. 317. 
las cosas que yo mande que se hiciesen..."; el monarca le recordó las leyes contra monipodios, recogiendo la de 1390, pero no la prohibió ${ }^{46}$. En Lequeitio (1488), "la mayor parte de los pobladores de la dicha villa que son mareantes é pescadores hobieron fecho una cofradía so la advocacion del Señor San Pedro é con ciertos capitulos é ordenanzas en grande agravio é perjuicio de nuestra justicia é juridicion Real, los cuales dis que so color de las dichas ordenanzas dis que conocen de muchos pleitos é causas que pertenescia conoscer á anuestra justicia é fasiendo ligas e monipodios é escandalos" ${ }^{\prime 7}$.

Estas situaciones condujeron a los Reyes Católicos a limitar algunos gremios y cofradías, pero de forma concreta y no genérica para todo el reino. Así, por ejemplo, en San Sebastián (1489) anularon la cofradía de Santa Catalina de mareantes, dando como argumento, entre otros, que:

"De los ayuntamientos de los pueblos se crecen algunos escándalos é otras alteraciones é inconvenientes [...] ansi por vias de cofradías como por ligas é monipodios que entre sí tienen, han acostumbrado de se levantar contra los alcaldes e jurados de la villa á son de escándalo é alboroto [...] muchas veces ha acaecido é acaeció no ser poderosos los dichos jurados é alcaldes, salvo de hacer é cumplir aquello que las dichas cofradías é los que las ligas é monipodios facian...".

Lo que llevó a los monarcas a disponer:

"...no sean osados en la dicha villa ni en su jurisdición de se juntar á voz de cofradía, ni hacer ayuntamiento alguno de gente, so color que lo hacen por algunas cosas necesarias, é para estar en orden en su oficio é arte, ni so otro color alguno...".

Sin embargo, ni en este caso extremo de extralimitación de una corporación laboral implicada en banderías políticas se llegó a su prohibición. Poco después, los soberanos establecieron que los cofrades eligiesen un mayordomo anual para juzgar, de forma exclusiva, "en los casos é cosas que por razon del dicho oficio de marear nacieren entre vosotros, fasta en cuantía de seis mil maravedis é no mas". A continuación se recogen los estatutos de la cofradía. Algo muy parecido ocurrió con la de pescadores de

46 Real Academia de la Historia, Col. Vargas y Ponce, t. XXXIX, 9/4207; Fernández, (1890), p. 241; Rumeu (1944), p. 145; y Erkoreka (1991), p. 41. Los cofrades de S. Pedro fueron multados por ruidos y alborotos contra el juez real. AGS, RGS, 1488-1, fol. 180; 1488-2, fol. 83; 1488-3, fol. 202; y 1489-1, fol. 282.

47 González (1829), I, pp. 185-186; Rumeu (1944), p. 145; Erkoreka (1991), p. 41; y Labayru (1968), III, pp. 413414. El representante de los Reyes las anuló y ordenó a la cofradía no actuar en asuntos propios de la justicia, pero ésta siguió conociendo en causas consideradas ajenas a su jurisdicción, puesto que los Reyes confirmaron lo ajustado a derecho y revocaron lo restante (García Fernández, 1995, p. 370). Un memorial (1530) expone que esta cofradía surgió para evitar la entrada de los mareantes en bandos: "se juntaron e reformaron la dicha cofradia por defenderse de los dichos escuderos e lecayos porque de otra manera ellos se echarian a perder" (García Fernández, 1995, p. 373). 
San Pedro, también donostiarra, proscrita ese mismo año por idénticas causas que la anterior y luego reconstituida con potestad en aspectos legales y provechosos ${ }^{48}$.

También es posible ver a los concejos haciendo colusiones. Así se denuncia en un pleito de 1507 iniciado en tiempos de los Reyes Católicos y según el cual algunos vecinos y el concejo de Bilbao, contra las leyes y ordenanzas del reino:

"No podiendo hacer de derecho, tenian fecho entre sí cierta liga é monipodio y estatutos á fin de cohechar é robar á los vecinos [...], tenian fecho un estatuto para que ningun vecino ni morador de la dicha villa no pudiese comprar en ella ni en su juridicion fierro ni acero por menudo á menos cantidad de cincuenta quintales juntos, ni los pudiese revender en tanta cantidad, ni en mas ni en menos so ciertas penas á fin de advocar para sí el trato, é que los que menos podían no pudiesen comprar fierro alguno, y que ellos lo comprarian al precio que quisiesen...".

Aparte de este oligopsonio, en los estatutos se contenían otros abusos, como no vender hierro al por menor mientras se cargaba la flota, impedir la entrada de bestias descargadas, obligar a comprar cestas nuevas para sardinas o incrementar las tasas del portazgo. Oligopsonios practicados desde más de cien años atrás, a veces amparados en privilegios reales, y en algunos casos sancionados por las ordenanzas concejiles $^{49}$.

48 González (1829), III, pp. 341-355; Erkoreka (1991), pp. 48 y 461; Imaz (1944), pp. 80-102; Díez (1985), pp. 273274; y García Fernández (1995), p. 371, y (2005), pp. 281-282. La reina prohibió a varias cofradías (1483), entre ellas la de Santiago (mercaderes y navieros), que entendiesen en el regimiento de Bilbao, pues lo habían intentado protagonizando ruidos (Labayru, 1968, III, p. 338; y García Fernández, 2005, p. 284). Otras cofradías conflictivas fueron las de Mondragón. La de tenaceros y porriqueros protagonizó (1479) disturbios para monopolizar el trabajo. Los tenaceros y zapateros, so color de cofradía, realizaron ligas y monipodios para vender a mayores precios. Los Reyes ordenaron guardar la ley de Juan I contra las ligas y monipodios (AGS, RGS, 1492-1, fol. 204) y más adelante el concejo denunció la existencia de una cofradía de tenaceros con posturas y monipodios (AGS, RGS, 1494-10, fol. 169). Las ordenanzas reales dadas a Guipúzcoa contra los bandos llevaron a Mondragón a redactar unas que impedían a ciertos artesanos ocupar cargos concejiles, para evitar la subida de precios (AGS, RGS, 1492-1, fol. 4). Más adelante los tenaceros informaban a los Reyes del quebrantamiento de la costumbre de elegir los cargos equitativamente entre los dos bandos locales (AGS, RGS, 1493-9, fol. 46). Tenemos noticias de un pleito entre dichos cofrades sobre unas ordenanzas (AGS, RGS, 1494-11, fol. 47). Su prior se quejó ante el Consejo Real por la elección de los oficios de la villa (AGS, RGS, 1499-8, fol. 128). Finalmente, estos bandos llevaron a los Reyes (1500) a prohibir las parentelas, parcialidades o cuadrillas por vía de bando en Galicia, Asturias, Cantabria, Vizcaya, Guipúzcoa y las Encartaciones, así como que se juntasen en forma de bandos, cofradías y linajes, quedando anuladas las ligas, confederaciones, promesas y capitulaciones entre los caballeros y escuderos. Nueva Recopilación (1982 [1640]), II, fol. 336r, VIII, XV, VI.

49 González (1829), II, pp. 6-39. Los regidores de Bilbao se acogieron (1518) a las prohibiciones reales para impedir una cofradía de escribanos (Enríquez, Hidalgo y Martínez, 2001, p. 1580) que había sido fundada al menos un siglo antes (Labayru, 1968, III, p. 61). En Vaquerín se hicieron confederaciones, monipodios y conspiraciones que enfrentaron a los vecinos por el asunto de las derramas concejiles (AGS, RGS, 1490-3, fol. 445). Los comerciantes de Cuenca se quejaron de la confederación y de la liga de los arrendadores de la greda de Magán para venderla solamente a ciertos compradores. AGS, RGS, 1494-12, fols. 110 y 399. 
Una última ley ${ }^{50}$ de carácter anticorporativo se debe a Carlos I (1552). He aquí una prohibición en toda regla, la única que para Castilla podemos considerar como proscriptora genérica de los gremios, similar a las vistas para Aragón y Navarra. Sin embargo, fue promulgada en una época tan tardía que no hará falta abundar en su nula repercusión, ni en que atendió a una mera reproducción jurídica. Pero, ningún autor ha sostenido, a partir de las taxativas prohibiciones de Carlos I, que los gremios dejasen de existir en la España moderna.

\section{Posibles explicaciones para un fenómeno universal}

Varias explicaciones he ido apuntando para un fenómeno complejo que atendió a multitud de causas. Veamos algunas otras.

Monsalvo niega que las medidas anticorporativas fuesen contrarias a las cofradías de oficio legalizadas, pero opina que las prohibiciones no tuvieron como fin frenar las aspiraciones políticas de la oligarquía local, que no habría estado detrás de las cofradías proscritas ${ }^{51}$. Una explicación que aporta para dichas prohibiciones es precisamente la alianza de la oligarquía ya instalada en el poder local con los reyes para impedir el ascenso de los artesanos ${ }^{52}$. Otra explicación, dada por Monsalvo e Iradiel ${ }^{53}$, alude a la situación de crisis económica, asociada a las restriccio-

"Otrosi mandamos que las cofradias que ay en estos reynos de oficiales se desfagan, y no las aya de aqui adelante, aunque esten por nos confirmadas, y que a titulo de los tales oficios no se puedan ayuntar, ni hazer cabildo, ni ayuntamiento; so pena de cada diez mil maraveddis y de destierro de vn año del reyno", Nueva Recopilación (1982 [1640]), II, Libro VIII, Título XIV, Ley IV, fol. 334r. Esta ley fue resultante de una petición de las Cortes de Madrid en 1551: “...una de las causas principales que havido de las carestías de todas las cosas en estos rreinos, es que cada officio tiene confradias y ordenanzas della [...] que non pueden entrar en ellas sino officiales de officio, y esto se juntan muchas vezes en el año, y resulta de las dichas juntas ponen precio a las cossas que han de vender, y esto veese claro porque no vender uno mas varato que otro, y si uno se encarga de una obra aunque la haga mal si el dueño se enoja con el no hay otro oficial que la tome, por que dize que va contra ordenanza..." (Cortes, 1866, V, p. 556). Quizá la coincidencia de esta ley en la Nueva Recopilación (1982 [1640], II, fol. 334r, XIV-IV) con las otras normas no referidas expresamente a gremios es lo que llevó a ciertos autores a considerar todas las proscripciones como relativas al mundo artesanal.

51 Monsalvo (1996a), p. 112. Sobre la alianza monarquía-oligarquía contra la ascensión artesanal, véase también Monsalvo (1996b), p. 55. Sin embargo sostengo (González Arce, 1991a, p. 319) que solamente los poderosos podían ser una amenaza al poder monárquico, y no el incipiente artesanado, como comparte Gautier-Dalché (1993, p. 16). No es extraño que en asuntos tan ambiguos como éste de la filiación de las cofradías proscritas surjan opiniones encontradas, en lo que no veo ánimos de resucitar antiguos debates historiográficos sobre el alcance del gremialismo (Iradiel, 1999, pp. 655-656), sino el deseo de llenar un vacío en la historiografía hispana; pues, como ha dicho Monsalvo (2002, p. 165), la función del historiador no sería afirmar o negar si hubo gremios, sino medir dónde y cuándo el corporativismo llegó a consumarse en la práctica.

52 Lo mismo que para Valencia. Iradiel (1993), pp. 266-269; y Benítez (1998), pp. 24-25.

$53 \quad$ Iradiel (1974), p. 73. 
nes de la oferta y la subida de precios. Una tercera ${ }^{54}$ la desarrollamos a continuación. Las prohibiciones anticorporativas han de ser puestas en el contexto europeo, pudiendo haber constituido desde una respuesta común a problemas semejantes hasta incluso un topos cultural de moda en la época (en referencia al triunfo de las ideas del orden o de la ética escolástica). Se trata de un hecho casi general en Occidente, con coincidencias cronológicas llamativas ${ }^{55}$, tal vez causadas por una mimesis jurídica.

También en la Roma clásica hubo corporaciones profesionales legalmente reconocidas, las collegia y sodalitia (que podemos traducir libremente por gremios y cofradías), al igual que abundantes ejemplos de organizaciones clandestinas con fines ilícitos, políticos entre otros, perseguidas por la ley ${ }^{56}$. Con Servio Tulio los colegios tienen características bien definidas, pero entre el 67 y 64 a.C., la ley Julia abolía algunos; en 59 eran restaurados por Julio César, quien volvía a abolirlos años más tarde $\mathrm{e}^{57}$. Tras César las corporaciones fueron reformadas e, incluso, Augusto pretendió abolirlas. Bajo el Imperio ninguna asociación podía existir sin autorización del príncipe. Probablemente, Augusto dejó subsistir los colegios antiguos y legítimos y

$54 \quad$ Monsalvo (1996a), p. 113.

55 Iradiel (1993), p. 266. Fueron prohibidas en Ferrara (1287), Brescia (1313), Milán (1316) y Alejandría (1339). El emperador Federico II prohibió (1233) toda clase de asociaciones y gremios debido a abusos, ligas y monopolios. Otra explicación se refiere a que los oficios tendieron a apartarse de la autoridad municipal y emprender su autonomía, por lo que fueron prohibidos en Tournai y Rouen, llegándose a una prohibición general en Francia (1280), que no fue respetada. En Inglaterra, por cuestiones policiales, Ricardo II prohibió todas las guildas, crafts y confraternidades de Londres; sin embargo, como en España, distinguió entre las devocionales y asistenciales, consentidas, y las corporativas, prohibidas o limitadas (Berengo, 1999, pp. 412-419; Ellul, 1999, p. 226; y Morales, 1974, p. 73). Diversas capitulares de Carlomagno y una del obispo de Reims (852) prohibieron cofradías que eran guildas de asistencia mutua. Los concilios de Rouen (1189), Montpellier (1215), Toulouse (1219), Burdeos (1255) y Aviñón (1202) sólo condenaron las cofradías de nobles o comerciantes. Martin Saint-Leon (1901), p. 14; y Morales (1974), pp. 70-71.

56 Los artesanos formaron colegios bajo un dios protector, con fiestas religiosas y banquetes sagrados. Según Plinio el Viejo y Plutarco, fueron legalizados por Numa Pompilio en ocho corporaciones. Luego, la Ley de las Doce Tablas les aseguró una libertad completa. Cracco (1971); Stemler (1887), pp. 3-5; y Rumeu (1944), p. 56.

57 Según Asconius un senadoconsulto prohibió los colegios, luego restablecidos por Clodio; el cual iría contra colegios de esclavos o artesanos participantes en tumultos. A pesar de todo, éstos continuaron turbando el orden público, por lo que Cesar suprimió las asociaciones, salvo aquéllas más antiguas. La explicación la encontramos en la existencia de diversas clases de asociaciones: "Collegia compitialitia", especie de cofradías religiosas de la plebe y la población servil, a las que se atribuyen desórdenes públicos; "Solidates sacrae", especie de cofradías de patricios; "Collegia Sodalitia", derivaciones de los anteriores utilizados para la conquista del poder, lo que explicaría su prohibición, que no afectó a las religioso-funerarias — tuvieron una existencia clandestina tras la ley Julia (67 a.C.), fueron legalizadas por Clodio (59 a.C.) para ser suprimidas de nuevo por César (56 a.C.) y definitivamente disueltas por Augusto-; y, por último, "Collegia artificum vel opificum", asociaciones puramente profesionales, a las que la ley Julia menciona como excepción, al ser las únicas no prohibidas, aunque sí rigurosamente reglamentadas. Digesto, Lib. XLVII, Tit. XII; García del Corral (1998), IV, pp. 719-720. 
los sometió a ciertas reglas generales contenidas en un senadoconsulto al que se alude en el Digesto, que debieron cumplir también los nuevos colegios que se constituyesen. Cuando un colegio quería hacerse autorizar debía antes someterse a lo dispuesto en aquél y obtener la autorización del príncipe, que sólo la daba tras una encuesta y deliberación del Senado. En adelante, los emperadores sólo autorizaron los colegios de oficios muy útiles a la población, bajo severas reglamentaciones. De manera que muchos pudieron establecerse bajo forma de asociaciones religiosas y funerarias, mientras que los emperadores se reservarían la posibilidad de prohibir las asociaciones políticas bajo apariencia de aquéllas. Desde Trajano, los emperadores favorecieron los colegios de artesanos. Marco Aurelio les concedió el derecho de aceptar legados, haciéndolos hereditarios y monopolistas. Pertinax y Antonino Pío se ocuparon de la inmunidad de las gentes de oficio. Finalmente, Alejandro Severo organizó todos los oficios en corporaciones, les otorgó una suerte de constitución municipal y les proveyó de defensores elegidos entre la corporación, concediéndoles jurisdicción para que resolviesen sus procesos. Se iniciaba por entonces la crisis a falta de conquistas y había que asegurar el abastecimiento de Roma ${ }^{58}$.

No hace falta insistir en el paralelismo entre la Roma clásica y lo ocurrido en España entre los siglos XII y XV, donde, en plena recepción del derecho común, los reyes prohibieron las cofradías subversivas de forma genérica, reiterativa y retórica, influidos por lo legislado en Roma y contenido en el Digesto ${ }^{59}$; si bien este hecho, como en Roma, no supondría que la prohibición se extendiese a las corporaciones lícitas. No es una casualidad la coincidencia entre la recepción del derecho común y la proliferación de la normativa anticorporativa. Ni tampoco que fuese Castilla, primera receptora del mismo, la que mayor abundancia generase de esta documentación. Recordemos a este respecto las clarificadoras palabras de Alfonso X, contenidas en Las Partidas ${ }^{60}$ ("Ayuntamiento e cofradias de muchos omes defendieron los sabios antiguos que non se fiziessen en las villas nin en los reynos, porque dello se leuanta mas mal que bien") y cómo en las mismas se copió, casi al pie de la letra, la prohibición contenida en el Código contra los monopolios ¿Qué son Las Partidas, si no derecho romano? ¿Quién introdujo el derecho romano, si no Alfonso X?

\footnotetext{
58 Rumeu (1944), p. 13; Martin Saint-Leon (1947), pp. 36-40; y Stemler (1887), pp. 9-22. En el siglo IV hubo nuevas regulaciones. García del Corral (1988), III, pp. 189-190.

59 En cuyo Libro XLVII, Título XXII, Ley I, se contiene un texto de Marciano donde se recoge la excepción que consentía los colegios profesionales frente a los prohibidos por la ley Julia. García del Corral (1998), IV, p. 719; Rumeu (1944), p. 11; y Martin Saint-Leon (1947), pp. 38-39. 


\section{Conclusión}

Gremios, corporaciones laborales y cofradías artesanales proliferaron en la Europa medieval y también en España. Aunque sus facultades y aspiraciones fueron en ocasiones recortadas y dirigidas desde el poder político, raramente fueron prohibidos de forma generalizada, salvo de manera puntual, temporal o retórica, sin efectos prácticos o de larga duración. Este aserto es igualmente válido para Castilla, reino donde se había interpretado, a partir de una extensa legislación anticorporativa, que no existieron gremios o corporaciones laborales durante el período medieval, debido a la persecución real. Por ello se hace preciso reinterpretar esa extensa documentación represora y determinar en qué medida afectó a organizaciones artesanales y a otro tipo de organizaciones con objetivos distintos a los de aquéllas.

La historiografía hispana viene abordando este asunto en los últimos años, pero no resulta fácil de dilucidar, pues el asociacionismo perseguido o reprimido es un fenómeno complejo con múltiples ramificaciones y una larga extensión en el tiempo y en el espacio. Las principales conclusiones a las que se ha podido llegar con estos estudios, incluido el presente, se sintetizan a continuación.

Entre los siglos XII y XVI diferentes colectivos se asociaron para conseguir diversos objetivos, para lo que adoptaron formas legalmente reconocidas, principalmente cofradías y hermandades de finalidad religiosa, mutualista y funeraria. Algunos, pese a mantener actividades lícitas, perseguían objetivos de otra índole, unos inofensivos, pero constituyendo otros una considerable amenaza para el poder establecido. A consecuencia de ello, los reyes, obispos y concejos prohibieron de forma general o concreta las cofradías y hermandades con finalidad diferente a la religioso-asistencial. Los protagonistas de esas asociaciones clandestinas, sobre todo en Castilla, fueron, las más de las veces, gentes poderosas que buscaban aumentar su poder, sobre todo político, pero ocasionalmente también económico. Se han documentado casos en la alta nobleza, artífice de confederaciones a favor o en contra de los diferentes reyes; en la pequeña nobleza local, protagonista de las banderías urbanas; así como en el patriciado urbano no noble, en ocasiones procedente de grupos mercantiles y artesanales, que buscaba puestos de poder a nivel local. En alguna ocasión, puede que los gremios participaran de este tipo de conspiraciones, por lo que se vieron afectados por las prohibiciones. No obstante, algunos de ellos aprovecharon su estructura corporativa para aspirar a conseguir mayores privilegios de carácter económico o laboral (subida de precios, restricciones a la competencia, control en la contratación de mano de obra, etc.), por lo cual se verían afectados, del mismo modo, por la legislación anticorporativa. Pero antes que ser prohibidos por la misma, simplemente les habrían sido recortadas o impedidas estas extralimitaciones.

Hasta aquí el principio de acción-reacción de una legislación que buscó poner coto a los excesos de poderosos y no tan poderosos, de nobles y oligarcas, y de sim- 
ples mercaderes, artesanos, pescadores y navegantes. Sin embargo, buena parte del acervo legislativo pudo atender a otras causas, sobre todo en el caso de Castilla. En primer lugar, parece que algunos reyes se limitaron simplemente a emitir normas proscriptoras emulando a sus progenitores, en un ejercicio de reproducción y reiteración jurídica que no atendía por tanto a situación real alguna. Pero la conclusión más novedosa que se puede extraer del presente trabajo es que una de las causas de tan abundante normativa anticorporativa fue la recepción del derecho común. Una situación similar a la vivida en la Europa bajomedieval se dio previamente en la Roma clásica, por lo que las autoridades republicanas, primero, y los emperadores, después, actuaron proscribiendo cierto tipo de asociaciones clandestinas con fines subversivos, sobre todo políticos, que adoptaron, como en la Edad Media, la forma de colegios profesionales o asociaciones religiosas o funerarias. Las autoridades romanas tuvieron la misma reacción que las medievales: prohibir estas asociaciones espurias mediante una abundante normativa, luego recogida en el Corpus Iuris Civilis, que como parte del derecho romano se reintrodujo en Europa a partir del siglo XII. Lo que, sin duda, indujo a los gobernantes europeos a emitir su propia legislación anticorporativa en un ejercicio de imitación jurídica.

\section{Bibliografía}

ALFONSO X (1985 [1555]): Las Siete Partidas, Madrid, Boletín Oficial del Estado (edición facsímil).

ARIAS DE SAAVEDRA, Inmaculada, y LÓPEZ MUÑOZ, Miguel Luis (1998):

"Cofradías y gremios de Navarra en la época de Carlos III", Hispania Sacra, 50 (102), pp. 667-695.

BENÍTEZ BOLORINOS, Manuel (1998): Las cofradías medievales en el Reino de Valencia (1329-1458), Alicante, Universidad de Alicante.

BERENGO, Marino (1999): L'Europa delle città. Il volto della società urbana europea tra Medioevo ed Età moderna, Turín, Einaudi.

BOFARULL Y DE SARTORIUS, Manuel (1876): Gremios y cofradías de la antigua Corona de Aragón. Colección de documentos inéditos del Archivo General de la Corona de Aragón, XL, Barcelona, Archivo de la Corona de Aragón.

BONACHÍA HERNANDO, Juan Antonio (1983): "La segunda mitad del siglo XIV y el siglo XV", en VALDEÓN BARUQUE, Julio (dir.), Burgos en la Edad Media, Valladolid, Junta de Castilla y León.

CALDERÓN ORTEGA, José Manuel (1999): Álvaro de Luna (1419-1454): colección diplomática, Madrid, Dykinson.

CAPELLA MARTÍNEZ, Miguel (1962): La industria en Madrid: ensayo histórico crítico 
de la fabricación y artesanía madrileñas, Madrid, Artes Gráficas y Ediciones.

CARANDE, Ramón y MATA CARRIAZO, Juan de (1968): El tumbo de los Reyes Católicos del concejo de Sevilla, Sevilla, Universidad Hispalense.

CARLÉ, María del Carmen (1954): "Mercaderes en Castilla", Cuadernos de Historia de España, XXI-XXII, pp. 146-238.

CARRASCO PÉREZ, Juan (1993): “Mundo corporativo, poder real y sociedad urbana en el reino de Navarra (siglos XIII-XV)", en Cofradías, gremios y solidaridades en la Europa medieval, Actas de la XIX Semana de Estudios Medievales, Pamplona, Gobierno de Navarra, pp. 225-251.

CASTRO, Américo, y ONÍS, Federico de (1916): Fueros Leoneses de Zamora, Salamanca, Ledesma y Alba de Tormes, Madrid, Centro de Estudios Históricos.

CHACÓN GÓMEZ-MONEDERO, Francisco Antonio (1998): Colección Diplomática del Concejo de Cuenca, 1190-1417, Cuenca, Diputación Provincial de Cuenca.

CLEMENTE RAMOS, Julián (1990): La sociedad en el Fuero de Cáceres (siglo XIII), Cáceres, Institución Cultural "El Brocense".

COLMEIRO PERNIDO, Manuel (1863): Historia de la economía política en España, Madrid, Cipriano López.

COLMENARES, Diego de (1969): Historia de la insigne ciudad de Segovia y compendio de las historias de Castilla, Segovia, Academia de Historia y Arte de San Quirce.

COLÓN, Germà, y GARCÍA, Arcadi (1980): Furs de València, Barcelona, Barcino.

CONTRERAS, Juan de (Marqués de Lozoya) (1921): Historia de las corporaciones en Segovia, Segovia, Mauro Lozano impresor.

Cortes de los antiguos reinos de león y de Castilla (1866), Madrid, Real Academia de la Historia.

CRACCO RUGGINI, Lellia (1971): “Le associazoni professionali nel mondo romanobizantino", Artigianato e tecnica nella società dell'alto medioevo occidentale. Actas del XVIII Setimane di studio del Centro Italiano di studi sull'alto medioevo, Spoleto, pp. 59-193.

DÍEZ DE SALAZAR, Luis Miguel (1985): “La industria del hierro en Guipúzcoa (siglos XIII-XIV). Aportación al estudio de la industria urbana", en La España Medieval, 6, pp. 251-276.

ELLUL, Jacques (1999): Histoire des institutions. Le Moyen Age, París, Presses Universitaires de France.

ENRÍQUEZ FERNÁNDEZ, Javier; HIDALGO DE CISNEROS AMESTOY, Concepción, y MARTÍNEZ LAHIGA, Adela (2000): Colección documental del archivo histórico de Bilbao (1501-1514), Donosti, Eusko Ikaskuntza.

-(2001): Colección documental del archivo histórico de Bilbao (1514-1520), Donosti, Eusko Ikaskuntza.

ERKOREKA GERVASIO, Josu Iñaki (1991): Análisis histórico-institucional de las cofradías de mareantes del País Vasco, Vitoria, Gobierno Vasco. 
ESTEPA DÍEZ, Carlos (1982): “Estado actual de los estudios sobre las ciudades medievales castellano-leonesas", en GARCÍA SASTRE, Juan José et al., Historia Medieval: cuestiones de metodología, Valladolid, Universidad de Valladolid, pp. 2781.

FALCÓN PÉREZ, María Isabel (1991): “Las cofradías artesanales de la Edad Media: aspectos religiosos y sociales", en La manufactura urbana i els menestrals (ss. XIII$X V)$. Actas de las IX Jornades de d'estudis historics locals, Palma de Mallorca, Gobierno Balear, pp. 193-222.

—(1994): "Las cofradías de oficio en Aragón durante la Edad Media”, Medievalismo, 4, pp. 59-79.

-(1997): Ordenanzas y otros documentos complementarios relativos a las Corporaciones de oficio en el reino de Aragón en la Edad Media, Zaragoza, Institución Fernando El Católico.

-(2001): "La manufactura del cuero en las principales ciudades de la Corona de Aragón", En la España Medieval, 24, pp. 9-46.

FERNÁNDEZ DURO, Cesáreo (1890): La marina militar de Castilla desde su origen y pugna con la de Inglaterra hasta la refundición en la Armada Española, Madrid, El Progreso Editorial.

FITA, Fidel (1889): "El Fuero de Uclés", Boletín de la Real Academia de la Historia, 14, pp. 302-355.

FUENTES GANZO, Eduardo (2003): “Cortes y fraternidades: asamblearismo político y derecho de asociación en Castilla y León medieval", en FUENTES GANZO, Eduardo, y MARTÍN, José Luis (dirs.), De las cortes históricas a los parlamentos democráticos. Castilla y León s. XII-XXI. Actas congreso científico, Madrid, Dykinson, pp. 137-170.

GARCÍA DE VALDEAVELLANO, Luis (1998): Curso de historia de las instituciones españolas, Madrid, Alianza.

GARCÍA DEL CORRAL, Ildefonso (1998): Cuerpo del derecho civil Romano, Valladolid, Lex Nova.

GARCÍA FERNÁNDEZ, Ernesto (1995): “Las cofradías de pilotos, mareantes y pescadores vascas (siglos XIV al XVI)", 118e Congrés National des Societés Historiques et Scientifiques, Pau (1993). L'aventure maritime, du golfe de Gascogne à Terre-Neuve, pp. 357-375.

-(2005): “Las cofradías de mercaderes, mareantes y pescadores vascas en la Edad Media", en ARÍZAGA BOLOMBURU, Beatriz y SOLÓRZANO TELECHEA, Jesús Ángel (eds.), Ciudades y villas portuarias del Atlántico en la Edad Media, Logroño, Instituto de Estudios Riojanos, pp. 257-294.

GARCÍA ORO, José (1987): Galicia en los siglos XIV y XV. Galicia urbana: Ciudades episcopales, Villas señoriales, Municipios realengos, La Coruña, Fundación Pedro Barrié de la Maza. 
GARCÍA RÁMILA, Ismael (1945): “Ordenamientos de posturas y otros capítulos generales otorgados a la ciudad de Burgos por el rey Alfonso X", Hispania, 1920-21, pp. 179-235, 385-439 y 605-650.

GAUTIER-DALCHÉ, Jean (1979): Historia urbana de León y Castilla en la Edad Media (siglos IX-XIII), Madrid, Siglo XXI.

-(1993): “L'artisanat urbain dans les pays de la couronne de Castille avant le regne des Rois Catholiques: Etat de la question", Razo, 14, pp. 9-19.

GONZÁLEZ, Tomás (1829): Colección de cédulas, cartas-patentes, provisiones, reales órdenes y otros documentos concernientes a las provincias vascongadas, Madrid, Imprenta Real.

GONZÁLEZ ARCE, José Damián (1991a): “Monarquía y gremios. Acerca de las corporaciones proscritas en la Castilla bajomedieval", en La manufactura urbana $i$ els menestrals (ss. XIII-XV). Actas de las IX Jornades de d'estudis historics locals, Palma de Mallorca, Gobierno Balear, pp. 311-327.

-(1991b): "Sobre el origen de los gremios sevillanos", En la España Medieval, 14, pp. 163-182.

-(2000): Gremios, producción artesanal y mercado. Murcia, siglos XIV y XV, Murcia, Universidad de Murcia.

-(2003): Documentos de Sevilla en el Archivo Municipal de Murcia. Fueros, Privilegios, Ordenanzas, Cartas, Aranceles (Siglos XIII-XV), Sevilla, Ayuntamiento de Sevilla.

-(2006): "Las formas de organización de los oficios relacionados con el mar en la Barcelona medieval (siglos XIII-XV)", III Congreso de Historia Marítima, Barcelona (22-24 noviembre).

-(2007): "Las cofradías de pescadores de Valencia, siglos XIII-XV", La pesca en la Edad Media. Congreso de la Sociedad Española de Estudios Medievales, Santiago de Compostela (7-9 de junio).

GONZÁLEZ GONZÁLEZ, Julio (1944): Alfonso IX, Madrid, CSIC-Instituto Jerónimo Zurita.

-(1983): Reinado y diplomas de Fernando III, 3 vols., Córdoba, Monte de Piedad y Caja de Ahorros.

HIDALGO DE CISNEROS, Concepción; LARGACHA RUBIO, Elena; LORENTE RUIGÓMEZ, Araceli, y MARTÍNEZ LAHIDALGA, Adela (1986): Colección documental del Archivo General del Señorío de Vizcaya, San Sebastián, Eusko-Ikaskuntza.

IMAZ, José Manuel (1944): La industria pesquera en Guipúzcoa al final del siglo XVI (Documentos de la época), San Sebastián, Diputación de San Sebastián.

IRADIEL MURUGARREN, Paulino (1974): Evolución de la industria textil castellana en los siglos XIII-XVI. Factores de desarrollo, organización y costes de la producción manufacturera en Cuenca, Salamanca, Universidad de Salamanca.

-(1993): "Corporaciones de oficio, acción política y sociedad civil en Valencia", en Cofradías, gremios, solidaridades en la Europa medieval. XIX Semana de estudios medievales, Pamplona, Gobierno de Navarra, pp. 253-284. 
—(1999): "Ciudades, comercio y economía artesana", en La Historia Medieval en España: un balance historiográfico (1968-1998), Actas de la XXV Semana de Estudios Medievales, Estella, Gobierno de Navarra, pp. 603-658.

LABAYRU, Estanislao Jaime (1968): Historia General del Señorío de Vizcaya, Bilbao, La Propaganda.

LÓPEZ BENITO, Clara Isabel (1983): Bandos nobiliarios en Salamanca al iniciarse la Edad Moderna, Salamanca, Centro de Estudios Salmantinos.

LÓPEZ FERREIRO, Antonio (1895): Fueros municipales de Santiago y de su tierra, Madrid, Castilla.

LÓPEZ MARTÍNEZ, Celestino (1948): “Organización corporativa de Sevilla en tiempos de San Fernando", Archivo Hispalense, 9, pp. 205-223.

LUMBRERAS VALIENTE, Pedro (1974): Los fueros de Cáceres. Su derecho público, Cáceres, Ayuntamiento de Cáceres.

MARTIN, José Luis (1983): Economía y sociedad en los reinos hispánicos de la Baja Edad Media, El Albir, Barcelona.

MARTÍN GRANIZO, León (1950): Apuntes para la historia del trabajo en España, Madrid, Federico Domenech.

MARTIN SAINT-LEON, Etienne (1901): Le compagnonnage: histoire, coutumes, règlements, rites, París, A. Colin.

-(1947): Historia de las corporaciones de oficio, Buenos Aires, Partenón.

MARTÍNEZ MORO, Jesús (1985): La tierra en la comunidad de Segovia. Un proyecto señorial urbano (1088-1550), Valladolid, Universidad de Valladolid.

MEÑACA, Mme. de (1982): "Implicaciones comerciales del Camino de Santiago en la zona donostiarra y guipuzcoana", Actas del Congreso El Fuero de San Sebastián y su época, San Sebastián, Eusko Ikaskuntza, pp. 193-216.

MONSALVO ANTÓN, José María (1996a): “La debilidad política y corporativa del artesanado en las ciudades castellanas de la meseta (primeros pasos, siglos XIII-med. XIV)", en CASTILLO, Santiago (coord.), El trabajo a través de la Historia, Madrid, Asociación de Historia Social, pp. 101-124.

—(1996b): "Solidaridades de oficio y estructuras de poder en las ciudades castellanas de la Meseta durante los siglos XIII al XV (aproximación al estudio del papel político del corporativismo artesanal)", en VACA LORENZO, Ángel (ed.), El trabajo en la historia, Jornadas de Estudios Históricos, Salamanca, Universidad de Salamanca, pp. 39-90.

-(2001): "Los artesanos y la política en la Castilla medieval. Hipótesis acerca de la ausencia de las corporaciones de oficio de las instituciones de gobierno urbano", en CASTILLO, Santiago y FERNÁNDEZ, Roberto (coords.), Historia social y ciencias sociales, Lleida, Milenio, pp. 291-319.

-(2002): “Aproximación al estudio del poder gremial en la Edad Media castellana. Un escenario de debilidad", En la España Medieval, 25, pp. 135-176.

MORALES BELDA, Fernando (1974): La Hermandad de las Marismas, Barcelona, Ariel. 
MUÑOZ Y ROMERO, Tomás (2000 [1847]): Colección de fueros municipales y cartas pueblas de los reinos de Castilla, León, Corona de Aragón y Navarra, Valladolid, Lex Nova (edición facsímil).

Nueva Recopilación ("Recopilacion de las leyes destos reynos hecha por mandado de la magestad catolica del rey don Felipe Segundo nuestro señor; que se ha mandado imprimir, con las leyes que despues de la vltima impresion se han publicado, la magestad catolica del rey don Felipe Quarto el grande nuestro señor", 1982 [1640]), Valladolid, Lex Nova (edición facsímil).

OLIVER, Bienvenido (1908): “Ordenamientos de la ciudad de Jaca. 1238”, Boletín de la Real Academia de la Historia, 52, pp. 345-361.

Ordenanzas de Sevilla (1975 [1632]), Sevilla, Colegio de Arquitectos de Sevilla (edición facsímil a cargo de PÉREZ ESCOLANO, Víctor, y VILLANUEVA SANDINO, Fernando).

PÉREZ MARCOS, Regina María (1995): “Fueros, cartas pueblas y privilegios de concesión real en Castilla-La Mancha (siglos XIII-XIV)", en ALVARADO PLANAS, Javier (ed.) Espacios y fueros en Castilla-La Mancha (siglos XI-XV). Una perspectiva metodológica, Madrid, Polifemo, pp. 141-177.

PÉREZ PÉREZ, Concepción (1973): “Comentarios al privilegio dado por Fernando El Católico para la reforma de los gremios en la ciudad de Lérida", en SARASA SÁNCHEZ, Esteban, y SERRANO MARTÍN, Eliseo (coords.), La Corona de Aragón y el Mediterráneo: aspectos y problemas comunes desde Alfonso el Magnánimo a Fernando el Católico (1416-1516): IX Congreso de Historia de la Corona de Aragón, Zaragoza, Institución "Fernando el Católico", pp. 245-251.

PRETEL MARÍN, Aurelio (1974): Alcaraz, un enclave castellano en la frontera del siglo XIII, Albacete, Instituto de Estudios Albacetenses.

-(1986): Conquista y primeros intentos de repoblación del territorio albacetense (Del período islámico a la crisis del siglo XIII), Albacete, Instituto de Estudios Albacetenses.

RECALDE RODRÍGUEZ, Amaia, y ORELLA UNZUE, José Luis (1988): Documentación real a la provincia de Guipúzcoa, siglo XV, 2 vols., San Sebastián, Eusko-Ikaskuntza.

RECUERO ASTRAY, Manuel; ROMERO PORTILLA, Paz, y RODRÍGUEZ PRIETO, María de los Ángeles (2000): Documentos medievales del Reino de Galicia. Fernando II (1155-1188), La Coruña, Xunta de Galicia.

REPRESA RODRÍGUEZ, Amando (1949): “Notas para el estudio de la ciudad de Segovia en los siglos XII-XV", Estudios Segovianos, I (2-3), pp. 273-319.

RIVERA RECIO, Juan F. (1976): La iglesia de Toledo en el siglo XII (1086-1208), Toledo, Diputación Provincial de Toledo.

RODRÍGUEZ MOLINA, José (dir.) (1983): Colección diplomática de Baeza: (siglos XII$X V)$, Jaén, Colegio Universitario "Santo Reino".

ROMERO MARTÍNEZ, Adelina (1995): “El asociacionismo del poder: las cofradías de hidalgos y caballeros", En la España Medieval, 18, pp. 135-162. 
RUMEU DE ARMAS, Antonio (1944): Historia de la previsión social en España. Cofradías, gremios, hermandades, montepios, Madrid, Revista de Derecho Privado.

-(1945): "Los gremios españoles. Su origen y vicisitudes", Revista de Trabajo. Congreso de Estudios Sociales, pp. 187-195.

RUIZ POVEDANO, José María (1989): Poder y sociedad en Málaga: la formación de la oligarquía ciudadana a fines del siglo XV, Málaga, Diputación Provincial de Málaga.

SÁINZ DIAZ, Valentín (1973): Notas históricas sobre la villa de San Vicente de la Barque$r a$, Santander, Institución Cultural de Cantabria, Centro de Estudios Montañeses. SÁNCHEZ HERRERO, José (1975): Los sínodos de la diócesis de León en los siglos XIII al XV. León y su historia, vol. III, León, Centro de Estudios e Investigación "San Isidoro".

—(1978): Las diócesis del reino de León: siglos XIV y XV, León, Archivo Histórico Diocesano.

-(1991): Las cofradías de Sevilla: historia, antropología, arte, Sevilla, Universidad de Sevilla. SANCHO SERAL, Martín Luis (1925): El gremio zaragozano del siglo XVI: (datos para la historia de la organización corporativa del trabajo en España), Zaragoza, Universidad de Zaragoza.

SOBREQUÉS, Santiago (1977): Baja Edad Media, en VICENS VIVES, Jaume, (dir.), Historia social y económica de España y América, Barcelona, Vicens Vives, pp. 1-356.

SOLÓRZANO TELECHEA, Jesús Ángel (1999): Colección documental de la villa medieval de Santander en el archivo general de Simancas (1326-1498), Santander, Ayuntamiento de Santander.

STEMLER, Oliver (1887): Droit Romain des colleges d'artisans, París, L. Larose et Forcel. TRAMOYERES BLASCO, Luis (1979 [1889]): Instituciones gremiales. Su origen y organización en Valencia, Valencia, Ayuntamiento de Valencia (edición facsímil).

UBIETO ARTETA, Antonio (1975): Jaca: Documentos municipales, 971-1269, Valencia, Anubar (Textos Medievales, 43).

UÑA SARTHOU, Juan (1900): Las asociaciones obreras en España. Notas para su historia, Madrid, Establecimiento Tipográfico de G. Juste.

UREÑA, Rafael de (1935): Fuero de Cuenca, Madrid, Real Academia de la Historia.

UREÑA, Rafael de y BONILLA, Adolfo (1907): Fuero de Usagre (siglo XIII): anotado con las variantes del de Cáceres, Madrid, Hijos de Reus.

VACA, Ángel; CUENCA, Juana; SÁNCHEZ, Carmen, y MATAS, Epifanio (1984): "Una ordenanza medieval del Concejo salmantino sobre el gremio de 'cortidores e çapateros' de la ciudad y su entorno económico y social", Salamanca. Revista Provincial de Estudios, 11-12, pp. 55-97.

VAL VALDIVIESO, María Isabel del (1994): “Ascenso social y luchas por el poder en las ciudades castellanas del siglo XV", En la España Medieval, 17, 157-184.

VICENS VIVES, Jaume, y NADAL OLLER, Jordi (1971): Manual de historia económica de España, Barcelona, Vicens Vives.

ZUMALDE IGARTÚA, Irene (1994): Colección documental del Archivo Municipal de Oñati (1149-1492), Donosti, Eusko Ikaskuntza. 